Section Editor Mitchell S.V. Elkind, MD, MS
Residency Training: Neurology training

\section{A comparison of Australian and American graduate medical education}

Petar Tcherveniakov, BMedSci (Hons), MBBS

Shaheen E. Lakhan, MD, $\mathrm{PhD}, \mathrm{MEd}, \mathrm{MS}$

Correspondence to Dr. Lakhan: slakhan@gnif.org
Neurology training varies significantly from country to country, with respect to length of working hours, intensity of work, exposure to subspecialties, and readiness for solo practice postresidency. This has been examined in part through surveys by the World Federation of Neurology. ${ }^{1,2}$ In Australia, neurology training closely mirrors the British system, from whence it was derived. Specialty training postgraduation follows a longer, sometimes more meandering course than what can be observed in the United States, but is often offset by a better quality of life during training.

As an Australian student from the University of Adelaide, my time at the Cleveland Clinic neurology department afforded me some insights into US adult neurology residency training, some of which is different from what is done in Australia. What follows is a brief examination of the 2 systems, and some points of contrast.

MEDICAL SCHOOL In Australia, there are several avenues by which medical school may be completed. Traditionally, undergraduate programs of 5 or 6 years were the most popular, allowing high-school graduates direct entry into the course after passing the relevant entrance requirements. Graduate entry programs of 4 years, similar to those available in the United States, have also long been an option for students with a prior, completed undergraduate degree. In recent years, there has been a move toward the latter, with established undergraduate programs, like the University of Melbourne, transitioning to a graduate entry model, following the completion of a generalist degree. $^{3}$

A more notable difference between the Australian and US systems is the absence of standardized national testing at the medical school level, like the US Medical Licensing Examinations (USMLE). Medical schools graduate students on the basis of internal examinations, the results of which cannot be compared across institutions - sometimes with a non-grade pass being the only indicator of academic performance postgraduation. ${ }^{4}$ The consequence of this is that a different system needs to be employed after medical school to stratify candidates for specialty programs.

RESIDENCY In the United States, students apply for neurology residency programs, usually associated with a single institution, in their final year of medical school. They are assessed on the basis of USMLE scores, curriculum vitae (CV), referee reports, and interview performance, and begin training in their program of choice postgraduation. Neurology programs are 4 years total, with a general medical intern year preceding 3 years of neurology-related rotations.

Australian graduates initially follow a less direct career path. Internship year is compulsory for all graduates to gain full medical registration, and this year is not associated with a specific specialty training program. Interns can tailor the year to their interests, so long as they complete at least one 10-week surgical, medical, and emergency medicine rotation. ${ }^{5}$ Internship allocations vary from state to state, some electing to use a CV and interview, while others employ a lottery system for intern allocation.

Following intern year, junior doctors may apply to become a basic physician trainee (BPT), and enter the generic 3-year pathway that precedes advanced training in 29 different medical specialties, including neurology. ${ }^{6}$ This is similar to the internal medicine pathway in the United States. For those who do not gain entry into the program, or choose not to apply immediately, there is the option to pursue an unaccredited year as a resident medical officer, rotating through various specialties, but not contributing to the requirements of the BPT program.

Each BPT program is usually tied to 1 or 2 hospitals. During the 3 years, trainees are rotated through specialist and general medical units, for 3 months at a time. For satisfactory completion of the program, trainees must also pass a written and clinical examination, both held in the third year of training. These barrier examinations are a standardized requirement for candidates nationwide. Pursuant to the successful completion of these examinations, the trainees can then apply for advanced training positions in their

From the School of Medicine (P.T.), University of Adelaide, Australia; the Neurological Institute (S.E.L.), Cleveland Clinic, OH; and the Global Neuroscience Initiative Foundation (S.E.L.), Los Angeles, CA.

Go to Neurology.org for full disclosures. Funding information and disclosures deemed relevant by the authors, if any, are provided at the end of the article. 
specialty of choice. This is a statewide process dependent on $\mathrm{CV}$, interview, and references, and candidates are not always successful in their first attempt, especially for competitive medical specialties.

Neurology advanced training is a further 3 years following the BPT program. There are 62 such positions, in contrast to the 2,207 residents and fellows that constitute the US neurology workforce-in-training. ${ }^{7.8}$ The first 2 years are considered core years, whereas the third is a more a flexible elective year. Advanced training experiences can vary significantly from hospital to hospital; however, during the first 24 months of training, all registrars (advanced trainees) are expected to spend 18 months in inpatient care of general neurology patients, 12 months on-call for neurologic emergencies and consultations within a general hospital, and 24 months of neurology ambulatory care, with a minimum of 1 clinic per week. ${ }^{9}$ These requirements are usually fulfilled concurrently during training at a secondary or tertiary referral center.

Australian registrars also sit for the American Academy of Neurology Residency Inservice Training Examination at the end of their second core year, for an informal indication of their level of knowledge.

The third year of advanced training is an opportunity for the registrar to explore an area of professional interest, such as stroke, epilepsy, and movement disorders-however, this is often limited by what is offered at the hospital of training. These are not considered formal fellowships, but can provide trainees the confidence to practice in these areas without further formal training.

LIFE DURING RESIDENCY The Australian system of training discussed thus far bears several notable differences to an American residency, especially with respect to lifestyle (table). The length of training is significantly longer in Australia, totaling at least 7 years, and often longer for candidates whose career trajectory does not follow the shortest path possible. However, the longer training is made more bearable by remuneration for rostered and unrostered overtime (hours worked over 37.5 hours per week)..$^{10}$ Although this remuneration is inconsistent from department to department, Australian trainee doctors can usually expect to be paid commensurate to the hours they have worked. This is in comparison to the salaries for American residents, which are generally flat rates regardless of hours worked, unless the resident chooses to moonlight.

Concordant with the longer overall period of training, each rotation during residency is also longer in Australia than it is in the United States-from internship (10 or 11 weeks rotations) to basic physician training (3 month rotations) to advanced training (12 months). This is in comparison to US intern rotations, which can often be no longer than 4 weeks each, and then no more than 3 months in later residency. This difference in the US system is likely balanced by longer working hours; however, they were notably limited to 80 hours by the Accreditation Council for Graduate Medical Education in 2003. ${ }^{11}$ Like in the United States, working hours vary significantly in Australian institutions. In a study of Australian neurology registrars, Lueck et al. ${ }^{10}$ demonstrated that weekly on-call requirements can range from 1.5 hours of general medicine call to 80 hours of neurology-specific call per week, with significant interhospital variation. The standard median work week was 40 hours (range 21-80), with an average of 8 hours of claimed unrostered overtime. Registrars also have the option of job sharing

Table Comparison of Australian and US neurology training

\begin{tabular}{|c|c|c|}
\hline & US neurology training & Australian neurology training \\
\hline Medical school & $\begin{array}{l}4 \text { years graduate study (preceded by } 4 \\
\text { years undergraduate) }\end{array}$ & $\begin{array}{l}5-6 \text { years undergraduate study (or } 4 \text { years } \\
\text { graduate preceded by } 3 \text { years undergraduate) }\end{array}$ \\
\hline Internship & Medical year & General year (includes surgery) \\
\hline Length & 3 years + internship & $\begin{array}{l}6 \text { years minimum ( } 3 \text { years BPT, } 3 \text { years advanced } \\
\text { training) + internship }\end{array}$ \\
\hline Remuneration for overtime & No & Yes \\
\hline $\begin{array}{l}\text { Possibility for part-time } \\
\text { training }\end{array}$ & No & Yes \\
\hline Differences for IMG applicants & ECFMG certification & AMC examinations or observed practice \\
\hline
\end{tabular}

Abbreviations: AMC = Australian Medical Council; BPT = basic physician trainee; ECFMG = Educational Commission for Foreign Medical Graduates; IMG = international medical graduate; RITE = Residency Inservice Training Examination. 
with another trainee during their elective year, which can allow for part time work over 2 years. ${ }^{9}$

INTERNATIONAL MEDICAL GRADUATES The pathway for international graduates into residency also deserves some consideration. In the United States, international medical graduates (IMGs) go through the same pathway as domestic applicants, namely the USMLE examinations, followed by a residency application with references and subsequent interview. As there are no national exit examinations for medical school in Australia, IMGs must follow a different pathway to demonstrate competency. The Australian Medical Council (AMC) allows unspecialized junior doctors to enter the Australian workforce through the Standard Pathway, which requires satisfactory performance in the AMC multiple choice question and clinical examinations, before attaining general medical registration. Trained neurologists can utilize the Specialist Pathway, which allows specialists to enter the workforce following a period of observed practice or further training, foregoing the aforementioned examinations. ${ }^{12}$

DISCUSSION It is accepted that neurology training in both the United States and Australia prepares trainees to become competent, self-sufficient specialists in their practice setting of choice. American residents go through an arguably harsher, albeit shorter training period, and are not as well remunerated for their hours as their Australian counterparts. Australian training, still closely resembling the British system from whence it developed, provides trainee doctors a better quality of life during training, but comes with the possibility of languishing in unaccredited positions for years at a time, if competition for training positions is high.

\section{STUDY FUNDING}

No targeted funding reported.

\section{AUTHOR CONTRIBUTIONS}

Both authors participated in the preparation of the paper and read and approved the final paper.

\section{DISCLOSURE}

The authors report no disclosures relevant to the manuscript. Go to Neurology.org for full disclosures.

\section{REFERENCES}

1. Steck A, Struha W, Sergay SM, Grisold W. The global perspective on neurology training: the World Federation of Neurology survey. J Neurol Sci 2013;334:30-47.

2. Bergen DC. Training and distribution of neurologists worldwide. J Neurol Sci 2002;198:3-7.

3. Roberts-Thomson RL, Kirchner SD, Wong CX. MD: the new MBBS? Med J Aust 2010;193:660-661.

4. Ingham A. The great wall of medical school: a comparison of barrier examinations across Australian medical schools. Aust Med J 2011;2:5-8.

5. South Australian Medical Education \& Training. Internship in South Australia. Available at: http://www.saimet. org.au/index.php/junior-doctors/interns/internship-in-sa. Accessed March 1, 2014.

6. The Royal Australasian College of Physicians. Specialty training programs. Available at: http://www.racp.edu.au/ page/atspecialties. Accessed March 1, 2014.

7. Australian and New Zealand Association of Neurologists. Recruitment of trainees. Available at: http://www.anzan. org.au/neurologytraining/recruitmentoftrainees.asp. Accessed March 1, 2014.

8. FREIDA Online. Specialty training statistics: neurology. Available at: https://freida.ama-assn.org/Freida/user/specStatisticsSearch.do? method $=$ viewDetail\&spcCd $=180 \&$ pagpageNum $=2$. Accessed July 18, 2014.

9. Australian and New Zealand Association of Neurologists. Advanced training. Available at: http://www.anzan.org.au/ neurologytraining/advancedtraining.asp. Accessed March $1,2014$.

10. Lueck CJ, Morris J, Pepper E. Job variation in Australian advanced training in neurology. Intern Med J 2008;38:549_558.

11. Philibert I, Friedman P, Williams WT. New requirements for resident duty hours. JAMA 2002;288:1112-1114.

12. Australian Medical Council. Assessment pathways. Available at: http://www.amc.org.au/index.php/ass/apo. Accessed March 1, 2014. 


\section{Neurology}

\section{Residency Training: Neurology training: A comparison of Australian and American graduate medical education}

Petar Tcherveniakov and Shaheen E. Lakhan

Neurology 2015;84;e38-e40

DOI 10.1212/WNL.0000000000001232

\section{This information is current as of February 9, 2015}

\section{Updated Information \&} Services

References

Subspecialty Collections

Permissions \& Licensing

Reprints including high resolution figures, can be found at: http://n.neurology.org/content/84/6/e38.full

This article cites 6 articles, 0 of which you can access for free at: http://n.neurology.org/content/84/6/e38.full\#ref-list-1

This article, along with others on similar topics, appears in the following collection(s):

All Education

http://n.neurology.org/cgi/collection/all_education Training-international

http://n.neurology.org/cgi/collection/training_international

Information about reproducing this article in parts (figures,tables) or in its entirety can be found online at:

http://www.neurology.org/about/about_the_journal\#permissions

Information about ordering reprints can be found online:

http://n.neurology.org/subscribers/advertise

Neurology ${ }^{\circledR}$ is the official journal of the American Academy of Neurology. Published continuously since 1951, it is now a weekly with 48 issues per year. Copyright @ 2015 American Academy of Neurology. All rights reserved. Print ISSN: 0028-3878. Online ISSN: 1526-632X.

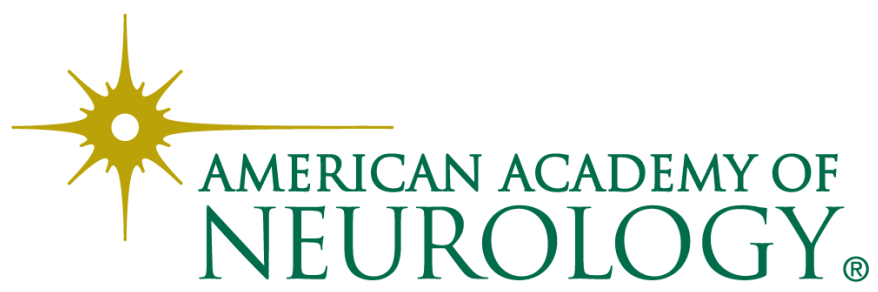

